\title{
Cost of gentamicin assays carried out by microbiology laboratories
}

\author{
P F Vacani, M M H Malek, P G Davey
}

\begin{abstract}
Aims-To assess the current range of prices charged for gentamicin assays in United Kingdom laboratories; and to examine the laboratories' likely response to increases or decreases in the demand for the service.
\end{abstract}

Methods-A postal survey of the 420 members of the Association of Medical Microbiologists was used to establish the range of prices charged for aminoglycoside assays. Additionally, eight private institutions were contacted to determine what the private sector was charging for aminoglycoside assays. Reagent costs in the NHS laboratories were calculated by dividing the total cost of all aminoglycoside assay kits by the number of samples analysed.

Results-The NHS and the private institutions both showed a wide price variation. Prices charged to an in-hospital requester for a peak and trough assay ranged from $£ 5 \cdot 00$ to $£ 68 \cdot 20(n=44)$, and to an external private hospital, under a bulk service contract, from $£ 5.00$ to $£ 96 \cdot 00(n=47)$. Prices charged by private laboratories ranged from $£ 49 \cdot 00$ to $£ 84.00(n=8)$. There was a log linear correlation in the NHS laboratories between the reagent costs per assay and the number of assays performed per year, and most laboratories thought that their price per assay would be sensitive to increases or decreases in demand. Laboratories which had purchased their assay machines had lower reagent costs per assay but higher repair and maintenance costs. Overall, number of assays performed and method of payment for assay machinery only accounted for $44.8 \%$ of the observed variation in assay kit costs.

Conclusions-The price range for gentamicin assays in the United Kingdom is wide and is only partially explained by the number of assays performed. Most laboratories believe that they would experience a reduction in unit cost as output increases. The currently offered range of prices is, in part, due to variation in the laboratories' approach to costing the service provided and some laboratories charge prices which do not even cover the cost of assay kits. Overall, we believe that prices charged should be as close as possible to the marginal cost of the tests performed.

$(\mathfrak{F}$ Clin Pathol 1993;46:890-895)

Economic evaluations of alternative health care programmes and procedures are increasingly required by decision makers and fund holders. Financial data can be used to ensure that maximum efficiency is achieved within health care budgets, thus helping to improve the efficient utilisation of available resources. Pharmaceutical products, which represent an important portion of health care expenditure, are an important area where economic evaluations can have a major impact on resource utilisation.

Included within many evaluation studies are costing analyses which seek to identify not just the acquisition costs of pharmaceutical products, but also the costs of related procedures, practices, improvements and problems. Such cost studies can be designed to show which treatment incurs the least total cost, and hence offer guidance over alternative drug selection.

The cost of performing an assay can be considered to be the financial expenditures necessarily incurred by the laboratory to perform the assay analysis (thus assay cost forms part of overall laboratory expenses). The price of an assay can be considered to be the monetary value charged by the laboratory to the assay requester (and as such represents part of the income of the laboratory). Recent emphasis on accountability and cost control within the National Health Service has provoked discussion on both costs and prices of individual activities. Procedures for assay analysis are no exception as there may be opportunities for improving the use of limited resources within microbiology laboratories.

Malek et $a l^{1}$ included the cost of gentamicin assays when comparing the cost of treatment with gentamicin combinations and ceftazidime monotherapy. This analysis of three United Kingdom hospitals showed a wide variation in the estimation of costs incurred by microbiology laboratories performing gentamicin assays. After adjustment of the costs quoted to 1992 prices, the average cost estimated by the three laboratories was $£ 44.27$ for a peak and trough assay, but the price ranged from $£ 38 \cdot 83$ to $£ 55 \cdot 18$. All three laboratories considered that the major
Correspondence to: Dr Peter Davey

Accepted for publication 5 May 1993 
component of the cost of an assay was contributed by fixed costs (equipment and staff). The lowest estimate of the variable (reagent cost) for performing one assay (either peak or trough) was $£ 4 \cdot 94$.

\section{Methods}

Data relating to microbiology laboratory activities and costs were drawn from a recent postal survey of the members of the Association of Medical Microbiologists. Surveys were sent to all 420 members and the respondents were asked to return their anonymous replies via the Secretary of the Association (thus ensuring complete anonymity of the respondent). Details of the questionnaire are given in the Appendix.

Eight private institutions offering assay monitoring tests were also contacted; of these, five were private hospitals and three were private laboratories. These were contacted to establish a guideline of alternative prices the fund manager or clinician would encounter if he or she were to consider sending their samples to a private laboratory.

Preliminary discussion with seven laboratories in England and Scotland suggested that it would be difficult, if not impossible, to assess fully overheads, staff costs, and financing of capital equipment used to perform gentamicin assays. The questionnaire asked for details about the cost of reagents, which constitutes most of the variable cost of an assay. Respondents were asked to estimate the total cost of performing an assay and to state whether this included labour or overheads. The unit cost of reagents per assay was calculated as follows:

Unit reagent cost $=$

Total annual cost of reagents (calibration + control + sample analysis)

Number of assays performed per year

The questionnaire also asked about the method of payment for the equipment used to perform gentamicin assays.

The responses to the survey, and from the private institutions were analysed using Minitab statistical software, release 8.

\section{Results}

Of the 420 sent out, $96(22 \cdot 86 \%)$ questionnaires were returned. Of these, $75(17 \cdot 86 \%)$ contained sufficient information to be included in our analysis. The actual response rate for each individual question varied considerably. It is accepted that there may be an element of bias, due to non-response, but we consider 75 usable replies to be a sufficient sample base of microbiology activity within the United Kingdom for analysis.

\section{ANALYSIS OF ASSAY PRICING}

The microbiologists' estimates of prices charged for assays vary widely, regardless of whether the request originates from within their hospital, or from an outside contractor, or a private hospital or patient (table 1). The mean price charged to in-hospital requesters for a peak and trough assay $(£ 25 \cdot 14)$ is above the mean price charged to external practitioners. Using the median as the measure of analysis, the price charged to an in-hospital requester is $£ 21.00$, with a range from $£ 5.00$ to $£ 68 \cdot 20$.

\section{PRICING POLICIES OF PRIVATE LABORATORIES} To make a comprehensive comparison of gentamicin assay pricing, eight private institutions who offered the service were contacted (five hospitals and three laboratories). Due to commercial sensitivity of the data being sought, only two questions were asked, the answers to both of which would be freely available to any interested party, namelywhat is the charge for performing one assay before and one after gentamicin is administered? What is the charge for performing 20 gentamicin assays? (this was taken to represent a basis for bulk purchase contracting).

The responses again showed a wide range of prices for a peak and trough assay $(£ 50.72$ to $£ 90 \cdot 00$ ). All of the private laboratories were prepared to offer lower prices for a bulk contract (table 1).

SENSITIVITY OF LABORATORIES TO ECONOMIES OF SCALE

Overall, the survey showed that the microbiologists consider their laboratories to be capable of either achieving reductions in unit assay costs with increased output, or at the very worst, to avoid additional unit costs with increased output (table 2). The estimated median cost fell progressively with increased demand and increased with decreased demand (table 2). The significance of differences between the median cost at each level of output ranged from 0.0009 to

Table 1 Price of assaying peak and trough gentamicin concentrations in samples from different sources

\begin{tabular}{|c|c|c|c|c|c|c|}
\hline Source of sample & $\begin{array}{l}\text { Number of } \\
\text { laboratories }\end{array}$ & Mean & Median & $\begin{array}{l}S D \\
\text { of mean }\end{array}$ & Minimum & Maximum \\
\hline \multicolumn{7}{|l|}{ NHS laboratories: } \\
\hline $\begin{array}{l}\text { In-hospital requester } \\
\text { Requester from a different }\end{array}$ & $\begin{array}{l}44 \\
41\end{array}$ & $\begin{array}{l}£ 25 \cdot 14 \\
£ 24 \cdot 88\end{array}$ & $\begin{array}{l}£ 21 \cdot 00 \\
£ 23 \cdot 60\end{array}$ & $\begin{array}{l}£ 13.90 \\
£ 11.74\end{array}$ & $\begin{array}{l}£ 5 \cdot 00 \\
£ 5 \cdot 00\end{array}$ & $\begin{array}{l}£ 68 \cdot 20 \\
£ 50 \cdot 00\end{array}$ \\
\hline $\begin{array}{l}\text { Private patient or foreign patient } \\
\text { Bulk service contract with a } \\
\text { private hospital }\end{array}$ & $\begin{array}{l}47 \\
28\end{array}$ & $\begin{array}{l}£ 34 \cdot 64 \\
£ 29 \cdot 22\end{array}$ & $\begin{array}{l}£^{30 \cdot 00} \\
£ 26.24\end{array}$ & $\begin{array}{l}£ 16.40 \\
£ 14.76\end{array}$ & $\begin{array}{l}£ 5 \cdot 00 \\
£ 7 \cdot 60\end{array}$ & $\begin{array}{l}£ 96.00 \\
£ 72.96\end{array}$ \\
\hline \multirow{2}{*}{$\begin{array}{l}\text { Private laboratories: } \\
\text { Single peak and trough } \\
\text { gentamicin assay } \\
\text { 20 peak and trough } \\
\text { gentamicin assays }\end{array}$} & 8 & $£ 70.20$ & $£ 71 \cdot 44$ & $£ 13.92$ & $£ 50.72$ & $£ 90.00$ \\
\hline & 8 & $£ 62.86$ & $£ 60.62$ & $£ 12.44$ & $£ 49.00$ & $£ 84.00$ \\
\hline
\end{tabular}


Table 2 Sensitivity of assay price to number of samples assayed

\begin{tabular}{|c|c|c|c|c|c|}
\hline $\begin{array}{l}\text { Change in number } \\
\text { of assays } \\
\text { performed }\end{array}$ & $\begin{array}{l}\text { Number of } \\
\text { respondents }\end{array}$ & $\begin{array}{l}\text { Median change } \\
\text { in predicted } \\
\text { assay price }\end{array}$ & $95 \%$ confidence intervals & $\begin{array}{l}\text { Range of change in } \\
\text { predicted assay price }\end{array}$ & $\begin{array}{l}\text { Significance } \\
\text { of difference } \\
\text { (Mann- } \\
\text { Whitney } U \text { test) }\end{array}$ \\
\hline $\begin{array}{l}\text { Decrease by } 50 \% \\
\text { Decrease by } 25 \% \\
\text { Decrease by } 10 \% \\
\text { Increase by } 10 \% \\
\text { Increase by } 25 \% \\
\text { Increase by } 50 \% \\
\text { Increase by } 100 \% \\
\text { Increase by } 200 \%\end{array}$ & $\begin{array}{l}31 \\
31 \\
31 \\
32 \\
32 \\
32 \\
33 \\
31\end{array}$ & $\begin{array}{l}\text { Increase by } 10 \cdot 00 \% \\
\text { Increase by } 5 \cdot 00 \% \\
0 \cdot 00 \% \\
\text { Decrease by } 0.50 \% \\
\text { Decrease by } 5 \cdot 00 \% \\
\text { Decrease by } 8 \cdot 35 \% \\
\text { Decrease by } 17 \cdot 50 \% \\
\text { Decrease by } 25 \cdot 00 \%\end{array}$ & $\begin{array}{l}\text { Increase by } 6.00 \text { to } 15.00 \% \\
\text { Increase by } 0.50 \text { to } 7.50 \% \\
\text { Increase by } 0.00 \text { to } 3.35 \% \\
\text { Decrease by } 0.00 \text { to } 2.50 \% \\
\text { Decrease by } 1.50 \text { to } 7.50 \% \\
\text { Decrease by } 5.00 \text { to } 12.50 \% \\
\text { Decrease by } 12.50 \text { to } 22.50 \% \\
\text { Decrease by } 17.5 \text { to } 32.5 \%\end{array}$ & $\begin{array}{l}\text { Increase by } 0.00 \text { to } 100.00 \% \\
\text { Increase by } 0.00 \text { to } 33 \cdot 10 \% \\
\text { Increase by } 0.00 \text { to } 12.00 \% \\
\text { Decrease by } 0.00 \text { to } 9.2 \% \\
\text { Decrease by } 0.00 \text { to } 42.00 \% \\
\text { Decrease by } 0.00 \text { to } 58.00 \% \\
\text { Decrease by } 0.00 \text { to } 65.00 \% \\
\text { Decrease by } 0.00 \text { to } 90.00 \%\end{array}$ & $\begin{array}{l}0.0167 \\
0.1024 \\
0.0009 \\
0.0368 \\
0.0946 \\
0.0096 \\
0.0971\end{array}$ \\
\hline
\end{tabular}

The Mann-Whitney test was applied to a comparison of each level of change in number of assays performed $-25 \%$ versus $-50 \%,-10 \%$ versus $-25 \%,+10 \%$ versus $-10 \%$, etc)

Figure 1 Relation between the number of aminoglycoside assays per year and the consumable (assay kit) costs per peak and trough assay. The laboratories are separated into those who purchased their assay machines (open squares, $n=16$ ) and those who have leased or loaned them (closed squares, $n=$ 51). Both groups show a log linear relation (fig B).
$0 \cdot 1024$ (table 2). At each level of increased or decreased demand, however, at least one laboratory estimated that their costs would be unaffected because the range of estimated change in cost always included 0 (table 2).

\section{RELATION BETWEEN ESTIMATED COST OF} CONSUMABLES AND PRICE CHARGED PER ASSAY Reagent, control, and calibration kits represent variable costs which cannot be avoided for gentamicin assay performance. Kits are marketed in different sizes and as such the best method of comparison is by unit cost. The survey showed a wide range of unit costs paid for these consumables, from $£ 3.20$ to $£ 25.00$ per peak and trough assay, and also a wide range of assays per year, from 73 to 6100 (fig 1A). The laboratories who had purchased their assay machines tended to have lower costs per peak and trough for any given level of throughput (fig 1A). Overall, the relation between throughput and consumables seemed to be exponential (fig 1A). This rela-
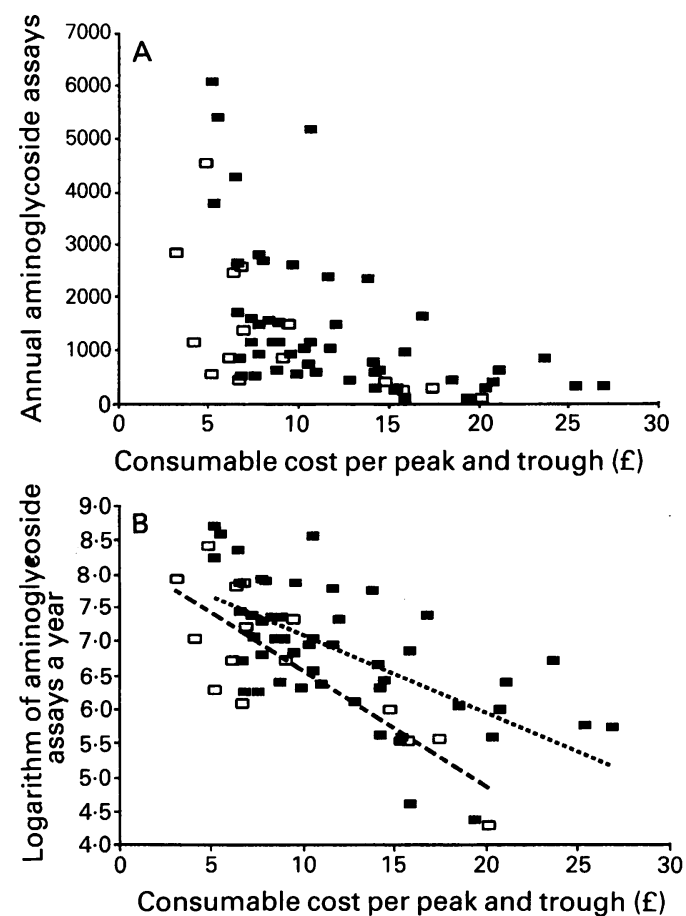$$
\text { - Free loan or lease 口 Purchase }
$$

... Ln assays $=8.29-(0.172 \times$ cost $)$

-- Ln assays $=8.26-(0.116 \times$ cost $)$ tion was confirmed by plotting the natural logarithm of assays per year against consumable costs (fig 1B) and by linear regression. For laboratories which purchased assay equipment adjusted $r^{2}$ was $64 \cdot 7 \%$ (p < 0.0001 ) and for laboratories which lease or rent it was $41.2 \%(p<0.0001)$. Combination of method of payment for assay machine and number of assays per year into a multiple regression gave an adjusted $r^{2}$ of $44.8 \%$. In other words these two factors combined account for $44.8 \%$ of the observed variation in consumable costs per peak and trough. To illustrate the extent of the remaining range of variation, laboratories with estimated unit costs of $£ 5$ or less per assay performed anything from 500 to 6000 assays a year and included examples of high and low throughput laboratories that had either purchased or leased/rented their assay machine (fig 1 ).

\section{FURTHER ANALYSIS OF ASSAY COSTS}

The results of the survey were used to test the hypothesis that laboratories which own the machinery necessary for gentamicin assay analysis will enjoy lower unit consumable costs (table 3 ). This analysis by machinery procurement mode includes the costs of assay kits used to provide reagents for patient assays, controls, and calibration divided by the number of assays performed in the period to derive the unit cost of consumables. The questionnaire also asked about total expenditure on repairs and maintenance in the past 12 months.

The 16 laboratories who had purchased their assay machines had higher repair and maintenance costs and lower reagent costs than the laboratories who loaned, leased, or rented machines (table 3 ). Of the latter group, 32/51 (63\%) paid no repair or maintenance charges, compared with four of 16 $(25 \%)$ of the laboratories who had purchased equipment $\left(\chi^{2}\right.$ test with Yates' correction 5.5; $\mathrm{p}<0.02)$. The range of repair and maintenance costs extended up to a maximum of $£ 8000$ for one laboratory which had purchased equipment and which only performed a total of 400 assays a year. This effectively added an additional $£ 40$ in direct cost to each pair of peak and trough assays performed. This laboratory charged $£ 4.36$ per pair of peak and trough assays, yet the reagent costs were $£ 7 \cdot 38$, giving a net loss of $£ 43.02$ per peak and trough assay on direct 
Table 3 Comparison of costs of reagent kits and repair or maintenance costs of assay machines by method of payment for assay machines for 67 laboratories who provided complete information

\begin{tabular}{|c|c|c|c|}
\hline Direct variable cost & $\begin{array}{l}\text { Purchased assay } \\
\text { machine }(n=51)\end{array}$ & $\begin{array}{l}\text { Free loan or lease of } \\
\text { assay machine }(n=16)\end{array}$ & $\begin{array}{l}\text { Significance of } \\
\text { difference (Mann- } \\
\text { Whitney U test) }\end{array}$ \\
\hline $\begin{array}{l}\text { Reagent kit cost per } p \\
\text { Median } \\
95 \% \text { CI } \\
\text { Range }\end{array}$ & $\begin{array}{l}\text { rough: } \\
£ 7 \cdot 87 \\
£ 5.85 \text { to } £ 11.91 \\
£ 3.16 \text { to } £ 20.20\end{array}$ & $\begin{array}{l}£ 9 \cdot 66 \\
£^{6} \cdot 57 \text { to } £ 13 \cdot 87 \\
£ 5 \cdot 18 \text { to } £ 26.92\end{array}$ & 0.0175 \\
\hline $\begin{array}{l}\text { Repair and maintena } \\
\text { cost per peak and tro } \\
\text { Median } \\
95 \% \text { CI } \\
\text { Range }\end{array}$ & $\begin{array}{l}£ 0 \cdot 91 \\
£ 0 \cdot 34 \text { to } £ 3 \cdot 25 \\
£ 0 \text { to } £ 40.00\end{array}$ & $\begin{array}{l}£ 0 \cdot 04 \\
£ 0 \text { to } £ 0 \cdot 22 \\
£ 0 \text { to } £ 16 \cdot 81\end{array}$ & 0.0152 \\
\hline $\begin{array}{l}\text { Reagent kit plus repa } \\
\text { and maintenance cos } \\
\text { peak and trough: } \\
\text { Median } \\
95 \% \mathrm{CI} \\
\text { Range }\end{array}$ & $\begin{array}{l}£ 9.66 \\
£ 6.57 \text { to } £ 13.87 \\
f 5.00 \text { to } f 54.75\end{array}$ & $\begin{array}{l}£ 11.66 \\
f 10.09 \text { to } f_{13.40} \\
f^{5.24} \text { to } f_{43.73}\end{array}$ & $0 \cdot 1317$ \\
\hline
\end{tabular}

Note that the median of the sum of reagent plus repair costs is not the same as the sum of the median reagent cost plus median repair cost.
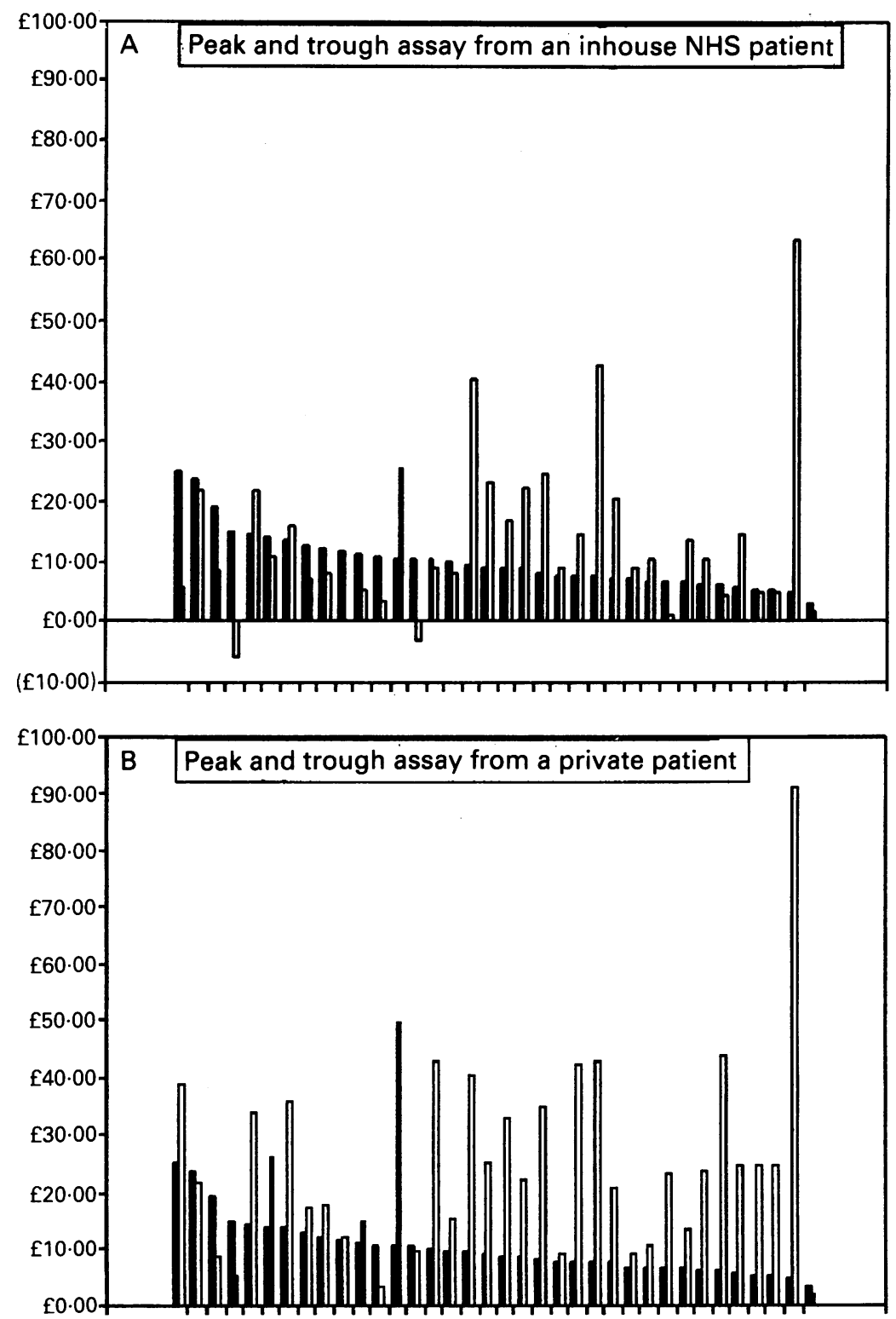

Consumable cost $\square$ Price minus cost

Figure 2 Price of peak and trough assay minus the cost per assay of consumables (reagent kits). The laboratories are arranged in descending order of reagent kit costs. $A$ negative value for price minus cost means that a laboratory is not charging enough to cover the cost of reagents. variable costs of reagents, repairs, and maintenance $(£ 40 \cdot 00+£ 7 \cdot 38-£ 4 \cdot 36)$.

\section{RELATION BETWEEN PRICE CHARGED AND}

COST OF ASSAY KITS

Subtracting the unit cost of consumables from the stated prices generates the contribution of each sample towards the fixed costs of the laboratory ("selling" price minus variable costs = contribution to fixed costs and contingencies). This contribution solely compares consumable costs with prices charged, and makes no allowance for repairs, maintenance, labour, overheads, financing, or other charges. Placing the laboratories in descending order of consumable costs per assay shows a wide variation in the difference between prices charged and consumable costs incurred (fig 2). Indeed, for two laboratories, the prices charged to NHS inpatients do not cover the consumable costs, as shown by the fact that price minus cost has a negative value (fig 2A). Prices charged to private patients covered consumable costs for all laboratories, but the range of differences was from $£ 2$ to $£ 90$ (fig 2B). The difference between price and consumable costs is what must be used to offset the other costs of performing aminoglycoside assays (repairs, maintenance, labour, overheads and finance costs).

\section{Discussion}

The price range for a pair of peak and trough samples in the present survey $(£ 5.00$ to $£ 68 \cdot 20)$ encompasses the range of estimated costs ( $£ 38 \cdot 83$ to $£ 55 \cdot 18$ ) observed in the previous study of three United Kingdom laboratories by Malek et al. ${ }^{1}$ In addition to a wide range of prices charged, the present study has also documented a range of $£ 5.00$ to $£ 54 \cdot 75$ in costs of assay kits plus repair and maintenance of assay machines (table 3 ). Other studies have also included the cost of a gentamicin assay in calculations of the total cost of gentamicin regimens. ${ }^{2-4}$ The figure used, however, has generally been the price of a gentamicin assay within the hospital where the study was conducted. An exception to this is a recently published study from the Netherlands. ${ }^{5}$ In this study the cost of aminoglycoside assays was calculated from Spaander points. These points reflect the overall contribution of each test to laboratory workload and costs. The total output of the laboratory is expressed in Spaander points, allowing calculation of an individual laboratory cost per Spaander point. This particular study used the average cost per Spaander point in the Netherlands to estimate a cost of NLG $37.40(£ 27 \cdot 70)$ per pair of peak and trough gentamicin assays.

Multicentre studies in the USA have shown considerable variations between hospitals in the prices charged for antibiotics ${ }^{6}$ and for administration of intravenous injections. ${ }^{7}$ One important source of such variation is the allowance that is made for staff and other overhead costs. ${ }^{6} \mathrm{~A}$ range of $\$ 1.00$ to $\$ 4.80$ for administration of intravenous injections however, was entirely accounted for by variation 
in hospital size, method of administration, and source of purchase of the equipment used for administration. ${ }^{7}$ We are not aware of any previous multicentre study of variation in aminoglycoside or other drug assay prices, although Broughton et $a l^{8}$ did analyse the costs of digoxin assay in one laboratory and compared overhead costs from two laboratories. The total cost of a digoxin assay in Hospital A was $£ 15 \cdot 60$, of which $£ 4 \cdot 80$ was accounted for by indirect, or overhead costs. Of the remaining $£ 10 \cdot 80, £ 8 \cdot 11, £ 1 \cdot 74$, and $£ 0.39$ were accounted for by consumables, staff, and direct capital equipment costs. Indirect overhead costs at Hospital B were $£ 3 \cdot 13$ per request, compared with $£ 4.80$ at Hospital A.

The cost of the reagents used to perform assays is in part determined by the number of assays performed. ${ }^{8}$ For tests based on assay kits, there is generally a stepwise increase or decrease in costs with changing demand, but over a representative period the average or median costs should be related to the number of tests performed. ${ }^{8} \mathrm{We}$ had therefore expected to find a relation between variable (reagent) costs and throughput. The answers to the questions about changes in assay price with throughput suggest that this is generally held to be true (table 2). The median assay price was sensitive to each proposed change in throughput, with significance levels varying from $0 \cdot 1024$ to $0 \cdot 0096$ (table 2). It should also be noted, however, that at least one laboratory stated that the price of gentamicin assays would not be affected by changes in throughput ranging from a $50 \%$ decrease to a $200 \%$ increase (table 2 ). The overall relation between throughput and consumable costs was exponential (fig 1), but some laboratories seem to be able to negotiate low reagent costs despite relatively low throughput. Overall throughput and method of machine purchase only accounted for $44.8 \%$ of the observed variation in kit costs per assay performed.

There are other important direct costs of kit assays which were not fully investigated. ${ }^{8}$ These include financing charges for capital where the machinery was purchased and depreciation, either of which may more than wipe out the savings made on consumables by laboratories which purchased assay machines. This will be most relevant for smaller laboratories with low throughput (where technical obsolescence may occur before machine decay). The potential scale of repair and maintenance charges is considerable, being more than $£ 1000$ a year for seven of $75(9 \%)$ of the laboratories. The assay machinery is probably used for other tests, however, and these costs are probably not directly attributable to aminoglycoside assays alone. In some laboratories all maintenance costs are averaged and distributed evenly across the costs of all tests. ${ }^{9}$ Inclusion of these additional direct variable costs further increases the inverse relation between variable costs and throughput. ${ }^{810}$ It should also be noted that the previous detailed analysis of all (direct and indirect) costs of gentamicin assays in three laboratories ${ }^{1}$ found that assay kit costs were only thought to account for $12 \%$ of the total cost of a peak and trough assay. The present study made no attempt to distinguish between batched aminoglycoside assays and individual, emergency requests. The method of analysing reagent costs provides an average for all samples. In fact, labour and reagent costs are likely to be higher for emergency requests. For example, 1990 costs of labour and materials for a digoxin assay at the Freeman Hospital, Newcastle, were $£ 0.423$ and $£ 2.972$ for a batched assay compared with $£ 2.022$ and $£ 4.020$ for a single, "stat" assay. ${ }^{9}$

How should individual laboratories respond to this information? They should certainly explore ways of reducing direct variable costs. The wide range of consumable costs for laboratories performing more than 1000 assays a year suggests that there is room for negotiation. The wide range of repair and maintenance costs also suggests that laboratory managers should ensure that they include these costs and explore the possibility of reducing them through renegotiation of packages with the equipment manufacturer. Overall, these negotiations will be most effective for laboratories with high throughput, in which it is possible to bring price close to marginal cost. ${ }^{11} 11$ For laboratories with low throughput, a balance must be struck between charging a realistic price and continuing to provide a service. ${ }^{10}$ It is debatable whether it would be practical for a laboratory with a small throughput to send gentamicin assays to another laboratory with more favourable costs, because of the need to provide rapid results and advice to clinicians. There is no doubt, however, that clinical budget holders will try to bring pressures on local laboratories to introduce prices which are comparable to larger, more distant laboratories. ${ }^{12}$ This preliminary analysis of general practice fundholders suggests that shopping around not only reduces price but can also improve the quality of service because some general practitioners reported that they received results more quickly from laboratories hundreds of miles away than from their own local laboratory. ${ }^{12}$ Moreover, the move towards once daily dosing of aminoglycosides will ensure that a higher proportion of patients receive adequate initial doses and may make a delay of up to 24 hours in receiving assay results acceptable. ${ }^{13}$ The concept of selling clinicians an overall service, as opposed to individual tests, has some virtues. ${ }^{14}$ Even in this system, however, laboratories must have some idea of the real variable costs attributable to sections of the laboratory-drug assays, for example-to identify significant variance between expected and actual costs. ${ }^{11}$ Like it or not, laboratories will increasingly be asked to provide information about the price of individual tests. Ultimately it is in the interests of the laboratory and its customers that the price quoted should reflect the true cost of tests. ${ }^{914}$

How should clinicians respond to price variation for gentamicin assays? There is no doubt that economic evaluation of gentamicin 
regimens will be sensitive to the range of prices which were encountered in this survey. For example, the conclusion that ceftazidime monotherapy may have a similar overall cost to aminoglycoside regimens was based on an average cost of $£ 44 \cdot 27$ per peak and trough assay at 1992 prices, so that substitution of $£ 5.00$ per assay would inevitably alter the conclusion. ${ }^{1}$ Clinicians working in hospitals with relatively high assay prices will need to be convinced that it is still reasonable to use aminoglycoside regimens and to send samples to the local laboratory. Experience in the United States shows that patients and clinicians are prepared to pay higher prices for tests performed locally. ${ }^{10}$ The advantages of local testing include more personal advice related specifically to the needs of the clinician or patient, as well as greater convenience. It may be important for laboratories to sell these services, however, as awareness of price variation grows among clinicians. There has been little published analysis of the impact on clinical practice of changes in laboratory practice. ${ }^{15}$ On the whole, we agree with previous authors ${ }^{8914}$ that clinicians need to be made aware of the total cost of tests, and that indirect costs, such as providing a local clinical microbiology service, should be built into the price of gentamicin assays. If the clinician is unaware of the real opportunity cost to the hospital of a service he or she will not be able to rank his or her priorities appropriately. This requires a policy shift, changing the laboratory from a service-providing cost centre to a service-selling accountable unit. Using pricing as a method of making laboratory charges more transparent and reactive to the demands of purchasing clinicians can serve to ensure more efficient use of available resources and thus help to improve health care in total. ${ }^{16}$

In conclusion, this survey has shown a wide variation in the prices being charged for gentamicin and other aminoglycoside assays. Only part of this variation can be explained by a variation in number of assays performed per year. At least as important is the fact that the relation between the cost of consumables and the price charged suggests that laborato- ries make radically different estimates of the remaining costs of the assay (fig 2). The prices quoted by some laboratories do not even cover their reagent costs, let alone other direct variable costs such as repair and maintenance of assay equipment. Such price variation will inevitably influence clinical decisions about the cost effectiveness of aminoglycoside regimens. Charging unrealistically low prices for aminoglycoside assays will also make clinicians undervalue a local clinical microbiology service.

We thank the Association of Medical Microbiologists and its members for assistance with the questionnaire used in thi paper.

Financial assistance for this project was provided by Lederle Laboratories.

The responsibility for errors and omissions remains with the authors and neither of the two organisations cited above are responsible for the views expressed in this paper.

1 Malek M, Lynch W, Wells $\mathrm{N}$, et al. A comparison of the costs of ceftazidime therapy and gentamicin combinations in three UK hospitals. $\mathcal{F}$ Antimicrob Chemother 1992;29:207-17.

2 Plumridge RJ. Cost comparison of intravenous antibiotic administration. Med $\mathcal{F}$ Aust 1990;153:516-8.

3 Rapp RP, Bannon CL, Bivins BA. The influence of dose frequency and agent toxicity on the cost of parenteral antibiotic therapy. Drug Int Clin Pharmacol 1982;16. 935-8.

4 Gladen HE. Computer modelling antibiotic therapy costs. Impact of therapeutic range. Drugs 1988;35(Suppl 2): 208-13.

5 Gyssens IC, van der Meer JWM, Lennards CA, Hekster YA. Cost of hospital antimicrobial chemotherapy. A method for global cost calculation. Pharmaceut Week Sci 1991;13:248

6 McCue JD, Hansen C, Gal P. Hospital charges for antibiotics. Rev Infect Dis 1985; 7:643-5.

7 Tanner DJ, Nazarian MQ. Cost containment associated with decreased parenteral antibiotic administration frequencies. $A m \mathcal{F}$ Med 1984;77(Suppl 4C):104-10.

8 Broughton PMG, Woodford FP. Benefits of costing in the clinical laboratory. $\mathcal{f}$ Clin Pathol 1983;36:1028-35.

9 Tarbit IF. Laboratory costing system based on number and type of test: its association with the Welcan workload measurement system. $f$ Clin Pathol 1990;43:92-7.

10 Eisenberg JM, Pauly MV, Myers MG. How will changes in physician payment by Medicare influence laboratory in physician payment by Medica

11 Travers EM. Cost analysis in the toxicology laboratory. Clin Lab Med 1990;10:591-623.

12 Glennerster $H$. General practice fundholding in the United Kingdom. Is it working? PharmacoEconomics 1993;3:10-3

13 Parker SE, Davey PG. Practicalities of once-daily aminoglycoside dosing. F Antimicrob Chemother 1993;31:4-8.

14 Dick HM. Costing of pathology services in the United Kingdom National Health Service. $f$ Clin Pathol 1991;44:705-9.

15 Sczepura AK, Stilwell JA. Information for decision makers at hospital laboratory level: an example of a graphical method of representing costs and effects for a replacemethod of representing costs and effects for a replacement automated technology in a

16 Stewart $M$. A patient's charter for laboratories. $B M \mathcal{F}$ 1992;304:251.
Appendix

Questionnaire sent to AMM members

1 What was the total number of aminoglycoside assay tests performed during the last twelve months?

2 What was the total number of gentamicin assays performed in the same period?

3 How many gentamicin assay kits were used in the same period (analysed by reagent, control and calibration)?

4 What was the standard number of samples in each gentamicin kit?

5 The machine(s) used to perform gentamicin assay is/are (tick): purchased/leased/on free loan/rented/other (please supply details).

6 What was the total expenditure on repair and maintenance of the assay machine(s) in this period?

7 What is the purchase cost of gentamicin kits for the laboratory (analysed by reagent, control and calibration)?
8 Is reagent kit price dependent on usage?

9 Please estimate the total cost to your laboratory for performing one gentamicin assay.

10 Does the estimate of total cost for a gentamicin assay include an allowance for:

(a) Labour? YES/NO/DON'T KNOW

(b) Overheads? YES/NO/DON'T KNOW

11 What do/would you charge the following parties for performing a peak and trough gentamicin assay:

(a) An in-hospital request?

(b) A request from a different hospital?

(c) A private patient/foreign patient request?

(d) An on-going bulk service contract with a private hospital?

12 Estimate the percentage change in the cost of performing a gentamicin assay if the annual throughput of gentamicin assays were to: Rise by $10 \%$; Rise by $25 \%$; Rise by $50 \%$; Rise by $100 \%$; Rise by $200 \%$; Fall by $25 \%$; Fall by $50 \%$. 